\title{
Development and bacteriological, chemical and sensory characterization of fishburgers made of Tilapia minced meat and surimi
}

\author{
[Desenvolvimento e caracterização bacteriológica, química e sensorial de "fishburgers" de \\ polpa e "surimi" de tilápia] \\ S.C.R.P. Mello ${ }^{1}$, M.Q. Freitas ${ }^{2}$, S.C. São Clemente ${ }^{2}$, R.M. Franco ${ }^{2}$, \\ E.B. Nogueira ${ }^{2}$, D.D.G.C. Freitas ${ }^{3}$ \\ ${ }^{1}$ Centro Universitário Augusto Motta (UNISUAM) - Rio de Janeiro, RJ \\ ${ }^{2}$ Universidade Federal Fluminense (UFF) - Niterói, RJ \\ ${ }^{3}$ EMBRAPA Agroindústria de Alimentos - Rio de Janeiro, RJ
}

\begin{abstract}
In this study fishburger samples obtained from tilapia minced meat and surimi retrieved from fillet frames - filleting process waste - have been assessed. Four different preparations of fishburger were made. Chemical analyses was performed for protein, lipids, moisture and ash assessments, as well as bacteriological analyses through mesophilic aerobic heterotrophic and psychrotrophic bacteria counts, isolation and identification of Salmonella spp., coagulase-positive Staphylococcus and fecal coliforms. Instrumental measurements were also carried out for texture and tested sensory acceptance. The costs of the ingredients used in the preparation of formulas were also assessed. Microbiological standards, established by current regulations, were met by all samples. No significant gap $(\mathrm{P}>0.05)$ was detected among the percentage of protein, moisture and ashes, while a significant gap $(\mathrm{P}<0.05)$ was verified for lipids. A significant gap $(\mathrm{P}<0.05)$ for the instrumental measurements of texture was also observed. Both surimi and minced meat fishburger presented good acceptance on sensory tests for taste, texture and overall impression. The use of smoked fish flavoring and surimi caused a considerable increase in costs due to ingredient acquisition. This study shows a positive result for the industrialization and consumption potential of fishburgers made of minced fish retrieved from fillet frames.
\end{abstract}

Keywords: minced fish, Oreochromis niloticus, proximate composition, fishery technology

\section{RESUMO}

Foram avaliadas amostras de "fishburgers" elaboradas com polpa e "surimi" de tilápia obtidos a partir do espinhaço residual da linha de filetagem. Realizaram-se análises químicas de proteína, lipídios, umidade e cinzas; análises bacteriológicas de bactérias heterotróficas aeróbias mesófilas e psicrotróficas; isolamento e identificação de Salmonella spp., Staphylococcus coagulase positiva e coliformes fecais; análises instrumentais de textura; teste de aceitação sensorial e levantamento de custo dos ingredientes utilizados na elaboração das formulações. Todas as amostras analisadas atenderam aos padrões microbiológicos estabelecidos pela legislação vigente. Não ocorreu diferença significativa $(P>0,05)$ entre os percentuais de proteína, umidade e cinzas, tendo sido observada diferença em relação ao percentual de lipídios entre as amostras. Observou-se diferença significativa entre as amostras avaliadas por análise instrumental, em relação à textura $(P<0,05)$. Tanto o "fishburger" elaborado com "surimi" quanto o elaborado com polpa, foram aceitos sensorialmente em relação ao sabor, textura e impressão global. A utilização de flavorizante à base de peixe defumado e do "surimi”, resultou em aumento considerável no custo com aquisição de ingredientes. Observa-se um resultado positivo em relação ao potencial de industrialização e consumo do "fishburger" elaborado com polpa de tilápia obtida do espinhaço residual da filetagem.

Palavras-chave: Oreochromis niloticus, análise centesimal, tecnologia de pescado

Recebido em 24 de julho de 2011

Aceito em 10 de maio de 2012

E-mail: silviaqua@uol.com.br 


\section{INTRODUCTION}

In Brasil, according to data published by the Instituto Brasileiro do Meio Ambiente e Recursos Naturais Renováveis (Brasil, 2007) fish production in 2007 was 1,072,226 tons, aquaculture alone accounting for $210,644.5$ tons. Farmed Tilapia production reached 95,091 tons whereas captured Tilapia accounted for 9,978 tons, in a total of 105,069 tons.

Simões et al. (2007) obtained Tilapia fillet yield values of $17.4 \%$ (skinless fillets) and $21.6 \%$ (fillet with skin) and the resulting waste products totaled $55.8 \%$ in average, its use being thus important. In such a context, with the use of mechanically deboned fish meat it becomes possible to make better use of fish resources and of many fresh water fish species, such as Nile Tilapia, which may be used as raw material in the production of minced fish and surimi, as well as other food products, which in turn may be employed in different food formulations. Such fact meets the need to diversify fish-made products (Marchi et al., 2000).

Under the current legislation (Brasil, 2001) limitations regarding the presence of some pathogenic bacteria spread through fish are provided for. In the case of refrigerated or frozen fish-made products, including burgers and like products, the following pathogenic bacteria limits are prescribed: coliforms at $45^{\circ} \mathrm{C}$, tolerance for indicative sample $\left(10^{3}\right)$; coagulasepositive Staphylococcus, tolerance for indicative sample $\left(10^{3}\right)$; and in the case of Salmonella spp., absence in $25 \mathrm{~g}$ of sample.

Technical regulations in the identification and quality of the burgers establish the minimum quality conditions of products and define Hamburger as a manufactured meat product obtained from ground meat with or without the addition of fat tissue and ingredients, molded and submitted to adequate technological process. The maximum fat percentage in its composition must be of $23 \%$ and the minimum protein percentage must be $15 \%$ (Brasil, 2000).

Effective tests aim to measure subjective attitudes such as acceptance or preference for products, individually or in relation to others. The determination of the acceptance of the product by consumers is an essential part of the development and improvement of products (Stone and Sydel, 1992).
According to Tokur et al. (2004) among readyto-cook products, burgers made of beef and chicken meat are the most popular ones in the world and fishburgers have seen their popularity increase. According to a market survey for tilapias and frogs, carried out by SEBRAE/RJ in the cities of Rio de Janeiro and Niteroi (Weichert et al., 2007), consumers associated the intake of Tilapia to a healthy and tasty diet and would be willing to consume derived products of easy preparation.

The objective of the present study was to develop and characterize fishburger made of Tilapia minced meat and surimi obtained through the processing of fillet frames from filleting process waste.

\section{MATERIALS AND METHODS}

Minced meat and surimi were used as basic ingredients for the preparation of fishburger samples, bacteriological, chemical and sensory characteristics being assessed for each different fishburger formulation as well as the costs for acquisition and preparation of the products.

Tilapia (Oreocrhomis niloticus) minced meat and surimi were used as raw material, obtained through the mechanical separation of fish muscles, fillet frames from the filleting process waste, according to the methodology described by Kuhn et al. (2004) and Mello et al. (2010). Minced fish and surimi samples, experimentally obtained in the fish industry under the oversight of the State of Rio de Janeiro, were stored and transported at $-18^{\circ} \mathrm{C}$, on the day after processing, to the Departamento de Tecnologia dos Alimentos da Universidade Federal Fluminense. Samples were kept at $-18^{\circ} \mathrm{C}$ for 30 days before being used. On the day before the preparation of the fishburgers, samples were kept under refrigeration overnight, at approximately $7^{\circ} \mathrm{C}$, for thawing.

Four different fishburger formulations were prepared. In two of them (one of minced fish and one of surimi) smoked fish flavoring was added (Table 1). The obtained patty was hand-molded in a circular shape with the help of a domestic mold. Each fishburger unit presented $90 \mathrm{~g}$ mean weight and $11 \mathrm{~mm}$ approximate thickness. The product was individually packed in plastic film and frozen in a domestic freezer unit $\left(-18^{\circ} \mathrm{C}\right)$. 
Development and bacteriological...

Table 1. Percentage of ingredients used in the different tilapia fishburger formulations

\begin{tabular}{|c|c|c|c|c|}
\hline Ingredients & $\begin{array}{c}\text { Formulation } 1 \\
(\%)\end{array}$ & $\begin{array}{c}\text { Formulation } 2 \\
(\%)\end{array}$ & $\begin{array}{c}\text { Formulation } 3 \\
(\%)\end{array}$ & $\begin{array}{c}\text { Formulation } 4 \\
(\%)\end{array}$ \\
\hline Minced fish & 86.67 & 86.17 & - & - \\
\hline Surimi & - & - & 86.67 & 86.17 \\
\hline $\begin{array}{l}\text { Textured } \\
\text { Soy } \\
\text { Protein (TSP) }\end{array}$ & 5 & 5 & 5 & 5 \\
\hline Salt & 1.2 & 1.2 & 1.2 & 1.2 \\
\hline Powder garlic & 1.5 & 1.5 & 1.5 & 1.5 \\
\hline Powder onion & 1.5 & 1.5 & 1.5 & 1.5 \\
\hline Canola Oil & 3 & 3 & 3 & 3 \\
\hline Fish flavor & - & 0.5 & - & 0.5 \\
\hline White pepper & 0.05 & 0.05 & 0.05 & 0.05 \\
\hline Nutmeg & 0.03 & 0.03 & 0.03 & 0.03 \\
\hline $\begin{array}{l}\text { Sodium } \\
\text { tripolyphosphate }\end{array}$ & 0.3 & 0.3 & 0.3 & 0.3 \\
\hline Sodium eritorbate & 0.25 & 0.25 & 0.25 & 0.25 \\
\hline $\begin{array}{l}\text { Monosodium } \\
\text { glutamate }\end{array}$ & 0.5 & 0.5 & 0.5 & 0.5 \\
\hline
\end{tabular}

Chemical parameters analyzed in triplicate were: protein, through the Micro Kjeldahl method, according to the AOAC (Association..., 1995), using a TE-036 digester and distillator set (Technal Lab, Piracicaba, Brazil); lipids, through the Soxhlet extraction method, with electrical heating (Osipan, Rio de Janeiro, Brazil); moisture, through the sterilizer method, at $105^{\circ} \mathrm{C}$, in a $315 \mathrm{SE}$ drying and sterilization sterilizer (Fanen, São Paulo, Brazil); ashes, through the incineration method, between 500 and $550^{\circ} \mathrm{C}$, in a 5.A muffle furnace (Eletroresistex, São Paulo, Brazil). Analyses for lipids, moist and ashes were carried out according to Brasil (1981).

The bacteriological analyses carried out in triplicate were: coagulase-positive Staphylococcus counting and identification (Brasil, 2003); Salmonella spp. isolation and identification (Brasil, 2003); counting of aerobic mesophilic heterotrophic bacteria (AMHB) and psychrotrophic aerobic heterotrophic bacteria (PAHB), according to the methodology recommended by Morton (2001) and Cousin et al. (2001), respectively; and determination of the most probable number (MPN) of Escherichia coli (Merck, 2002 modified by Franco and Mantilla, 2004).

In the texture instrumental analysis, the hardness of fishburger samples made of minced fish and surimi was assessed. Trials were carried out in the TA-TX2 texturometer (Stable Micro Systems - Texture Analyser) in EMBRAPA Sensory and Instrumental Analysis Laboratory. Samples presenting $90 \mathrm{~g}$ mean weight and $15 \mathrm{~mm}$ thickness were kept under refrigeration for 12 hours in order to defrost and at $10 \pm 3^{\circ} \mathrm{C}$ temperature until the trial. A $36 \mathrm{~mm}$ wide cylindrical probe $(\mathrm{P} / 36)$ 
was used for the compression of the sample at $2 \mathrm{~mm} / \mathrm{s}$ up to $10 \mathrm{~mm}$ of its thickness. Hardness was defined as the maximum positive strength (first peak) obtained in the compression curve. Determinations in two distinct batches produced with minced fish and surimi were performed in six replicates.

An acceptance test (Stone and Sidel, 1992) was carried out with 44 randomly chosen untrained assessors, being 16 men and 28 women, aged from 19 to 60 years old, in individual booths equipped with white lighting. Portions of the four fishburger formulations were served on disposable plates codified by random three digit numbers accompanied with water and crustless bread slices. The different formulations were presented to each assessor one after the other in a random sequence. The degree of acceptance was represented by a structured 9-point hedonic scale, varying between "liked it very much" (9) and "disliked it very much" (1). Making use of a form containing a structured scale, each assessor expressed the degree of acceptance for three attributes (taste, texture and overall impression). On the same form the assessors also expressed their attitude towards consumption by means of a 9-point structured attitude scale (Fact), varying from "would eat it whenever possible" (9) to "would only eat it if forced to" (1). The assessors were informed that the test product was a "fishmade hamburger" without any specification regarding the kind of meat used in its formulation.
Results of physicochemical and sensory analyses were assessed through variance analysis, and the comparison between mean values through Tukey's test (5\% probability level), using SAS software - Statistical Analytical System (Statistical, 1999).

\section{RESULTS AND DISCUSSION}

The costs with additives and ingredients used in minced meat and surimi fishburger elaboration can be observed in Table 2. The final cost for the production of one kilo of fishburger with no added flavor was BRL $\$ 1.15$ cheaper than that of fishburger with added flavor, regardless of the raw material used (minced fish or surimi). Since the flavoring (smoked fish flavor) used in this study was imported, it was expensive. No similar national product with the appropriate specification was found in the market. When using minced fish as raw material, it was possible to reduce the cost of ingredient acquisition in BRL $\$ 0.70 / \mathrm{kg}$ when compared to the use of surimi. According to Regenstein (1986), the production of surimi requires a specific technological process as well as the addition of cryoprotectants to maintain the characteristics of the final product gel. Due to this process there is an increase in production costs which can be considered a disadvantage in the transformation of minced fish into surimi.

Table 2. Cost per produced kilo (BRL $\$ / \mathrm{kg}$ ) of additives and ingredients used in the elaboration of the different fishburger formulations

\begin{tabular}{ccccccc}
\hline Formulations & $\begin{array}{c}\text { Minced fish (cost of } \\
\text { added ingredients) }\end{array}$ & $\begin{array}{c}\text { Surimi } \\
\text { (cost of added } \\
\text { ingredients) }\end{array}$ & Spices & Additives & $\begin{array}{c}\text { Smoked fish } \\
\text { flavor }\end{array}$ & Total \\
\hline 1 & 0.009 & - & 0.040 & 0.485 & - & $* 0.53$ \\
2 & 0.009 & - & 0.040 & 0.485 & 1.15 & $* 1.68$ \\
3 & - & 0.71 & 0.040 & 0.485 & - & $* 1.23$ \\
4 & - & 0.71 & 0.040 & 0.485 & 1.15 & $* 2.38$
\end{tabular}

$* \mathrm{R} \$ 1,00=\mathrm{US} \$ 2,17 \quad($ October 2008) 
In Table 3, results of the bacteriological analyses for frozen minced meat and surimi fishburgers, for the frozen raw materials (minced fish and surimi), and for both kinds of fishburger after Table 3. Results of bacteriological analyses of frozen and fried fishburger and of raw materials used (minced fish and surimi)

\begin{tabular}{|c|c|c|c|c|c|}
\hline Sample & $\begin{array}{l}\text { AMHB } \\
(\mathrm{Log} 10 \\
\mathrm{UFC} / \mathrm{g}) \\
\end{array}$ & $\begin{array}{l}\text { PAHB } \\
(\log 10 \\
\text { UFC/g) } \\
\end{array}$ & $\begin{array}{l}\text { Coagulase-positive } \\
\text { Staphylococcus } \\
\text { (Log10 UFC/g) }\end{array}$ & $\begin{array}{l}\text { Salmonella } \\
\text { spp. }\end{array}$ & $\begin{array}{l}\text { Fecal coliforms } \\
\text { (Log10 NMP) }\end{array}$ \\
\hline $\begin{array}{c}\text { frozen } \\
\text { fishburger } \\
\text { (minced fish) }\end{array}$ & 8.11 & 9.99 & absence & absence & absence \\
\hline $\begin{array}{l}\text { frozen } \\
\text { fishburger } \\
\text { (surimi) }\end{array}$ & 2.3 & absence & absence & absence & absence \\
\hline $\begin{array}{l}\text { fried fishburger } \\
\text { (minced fish) }\end{array}$ & absence & absence & absence & absence & absence \\
\hline $\begin{array}{l}\text { fried fishburger } \\
\qquad \text { (surimi) }\end{array}$ & absence & absence & absence & absence & absence \\
\hline \multicolumn{6}{|l|}{$\begin{array}{l}\text { Raw material } \\
\text { (minced fish) }\end{array}$} \\
\hline \multicolumn{6}{|l|}{$\begin{array}{l}\text { Raw material } \\
\quad \text { (surimi) }\end{array}$} \\
\hline & 6.06 & 6.0 & absence & absence & absence \\
\hline
\end{tabular}

AmHB: aerobic heterotrophic bacteria; PAHB: psychrotropic aerobic heterotrophic bacteria; NMP: most probable number.

Results for frozen fishburger samples AMHB and PAHB varied from 2.3 to $9.99 \log 10$ $\mathrm{UFC} / \mathrm{g}$; there are no limits for the counting of aerobic heterotrophic bacteria for this type of product or the like in the Brazilian legislation. Vieira (2004) stressed that these analyses are used in the industry to assess the efficiency of processing, i.e., how much the number of bacteria increased or decreased during manufacturing phases.

AMHB and PAHB found for frozen fishburgers made of minced meat were relatively high. This could be associated to the kind of handling during the process of raw material retrieval. Surimi was submitted to three washing cycles with chlorinated water at $5 \mathrm{ppm}$, which probably reduced the level of contamination in relation to minced fish, which was only submitted to being fried for 3 minutes on each side, reaching $79^{\circ} \mathrm{C}$ temperature in the heart of samples, are expressed. 
$1.30 \pm 0.03$, for surimi fishburger. Although minced meat fishburger presented a higher protein percentage when compared to surimi fishburger, there was no significant difference between them $(\mathrm{P}>0.05)$. The values observed are above the minimum protein content $(15 \%)$ established for hamburgers made of livestock meat under the current legislation (Brasil, 2000). Also, no significant difference was found among the results obtained in moisture and ashes analyses $(\mathrm{P}>0.05)$.

A significant difference $(\mathrm{P}<0.05)$ was observed in relation to the percentage of lipid in the samples. This is explained by the kind of raw material used. During the washing cycles in the surimi processing, large amounts of supernatant fat were removed, decreasing the percentage of lipids in the product. Coelho et al. (2007) worked with fishburger made of Hake (Merluccius hubsi) surimi and found lipid percentages varying from 0.37 to 0.41 , depending on the formulations adopted, close to the values found for surimi fishburger in the present study. These authors found lower lipid percentages in fishburger when compared to the percentage found in fresh fish $(1.02 \%)$ before the processing of surimi, confirming once again the results of the washing process in removing fat. Marengoni et al. (2009) found lipid percentages between 1.7 and 10.3 in fishburgers made of mechanically deboned Tilapia meat, the highest values being observed in formulations with $8 \%$ of vegetable fat added. Those values are higher than the maximum percentage found in the formulations elaborated in this study.

Tokur et al. (2004) analyzed Tilapia fishburger samples using $77.4 \%$ of fillet comminuted in a food processor and obtained values similar to those found in the present work regarding the percentage of protein, lipid and ashes, respectively $(17.8 \%, 5.3 \%$ and $2.6 \%)$.

The mean values and standard deviation found for the instrumental analyses concerning hardness of raw and refrigerated fishburger samples made of minced fish and surimi were, respectively, $1,345.3 \mathrm{~g} \pm 647.93$ and $340.4 \mathrm{~g} \pm 53.94$, a significant difference being observed $(\mathrm{P}<0.05)$. During the processing of fishburger it was observed that surimi became sticky and less hard than minced fish, making preparation difficult. Chen and Huang (2008) reported that the high viscoelasticity of surimi is an important quality characteristic, however, it makes processing more difficult.

Results of the sensory acceptance test can be seen in Table 4. Fishburgers made of minced fish obtained better acceptance than those made of surimi, a significant difference being observed between the samples $(\mathrm{P}<0.05)$.

Table 4. Mean and standard deviation values obtained in the Acceptance Test of the four Tilapia fishburger formulations

\begin{tabular}{ccccc}
\hline Sample & Taste & Texture & $\begin{array}{c}\text { Overall } \\
\text { impression }\end{array}$ & Attitude \\
\hline $\begin{array}{c}\text { minced meat } \\
\text { fishburger } \\
\text { (with flavor) }\end{array}$ & $7.57 \mathrm{a} \pm 1.17$ & $7.25 \mathrm{a} \pm 1.14$ & $7.40 \mathrm{a} \pm 1.17$ & $6.52 \mathrm{a} \pm 1.42$ \\
$\begin{array}{c}\text { minced meat } \\
\text { fishburger } \\
\text { (without flavor) }\end{array}$ & $7.18 \mathrm{a} \pm 1.12$ & $6.97 \mathrm{a} \pm 1.57$ & $7.14 \mathrm{a} \pm 1.19$ & $6.32 \mathrm{a} \pm 1.25$ \\
$\begin{array}{c}\text { surimi fishburger } \\
\text { (with flavor) }\end{array}$ & $5.15 \mathrm{~b} \pm 0.33$ & $5.81 \mathrm{~b} \pm 2.13$ & $5.54 \mathrm{~b} \pm 2.13$ & $4.48 \mathrm{~b} \pm 2.03$ \\
$\begin{array}{c}\text { surimi fishburger } \\
\text { (without flavor) }\end{array}$ & $5.13 \mathrm{~b} \pm 1.97$ & $5.66 \mathrm{~b} \pm 1.95$ & $5.40 \mathrm{~b} \pm 1.92$ & $4.36 \mathrm{~b} \pm 1.77$
\end{tabular}

Mean values in the same column followed by different letters presented significant difference $(\mathrm{p}<0.05)$ 
No significant difference $(\mathrm{P}>0.05)$ was observed in relation to the addition of smoked fish flavor neither among samples made of minced fish nor among those made of surimi. However, a tendency for better acceptance of the flavored product was observed. For the flavored minced meat fishburger, $59 \%$ of panelists graded the samples eight and nine regarding the taste attribute ("Liked it very much", "Loved it", respectively); for the same, but flavorless, product, $41 \%$ graded the samples eight and nine regarding the same attribute. Both surimi and minced meat fishburger, regardless of flavoring, were sensorially accepted with regard to taste, texture and overall impression, reaching abovefive means in the hedonic scale.

The sweetish taste of the surimi-made product played a role in its reduced acceptance. Twentytwo consumers, corresponding to $50 \%$ of the total, indicated that these samples presented a slightly sweet taste when explaining their lower grading. Manley and Mankoo (2004) showed that one must be particularly careful with the use of sugars as cryoprotectants in surimi. Depending on the kind of sugar used, one may obtain a sweet taste, unsuitable for such product. The surimi used in this study presented a sweetish taste, which could have been attenuated by the use of a sorbitol cryoprotectant in the place of sucrose. Nevertheless, being an imported product, the use of sorbitol cryoprotectants could raise production costs, preventing their use by small manufacturing companies. The addition of greater amounts of some additives and spices could probably help reduce the sweetish taste.

Tokur et al. (2004) assessed the acceptance of fishburgers made of Tilapia fillets comminuted in a food processor using the 9-point hedonic scale and obtained mean values between 7.8 and 9 for color, smell, taste, texture, and overall impression attributes. Marengoni et al. (2009), through the sensory testing of four different fishburger formulations elaborated with Tilapia MDM for taste, smell, smoothness and overall appearance, obtained mean values varying from 7.1 to 7.5 , within the level of moderately accepted to well accepted. Results of these authors converge with those found in the present study for Tilapia minced meat fishburgers, confirming the acceptance of the product and its potential for consumption.
Regarding attitude (intention to consume), only fishburgers made of minced meat were well accepted. Those made of surimi reached lower mean values, corresponding to the term "would occasionally eat it". Marengoni et al. (2009) assessing the intention to consume fishburgers made of Tilapia MDM, obtained mean values ranging from 3.86 and 3.98, showing results between "maybe would buy it/maybe wouldn't buy it" and "would possibly buy the product", these values being below those of the present research.

\section{CONCLUSIONS}

Tilapia minced meat and surimi obtained from filleting process waste fillet frames are intermediary raw materials with potential for fishburger elaboration. Both frozen fishburger samples and fried ones complied with the microbiological limits established by the current legislation. Considering the minimum protein and maximum fat standards for hamburgers made of livestock meat, both minced meat and surimi fishburgers complied with standards prescribed by legislation. The use of minced fish resulted in a reduction of ingredient acquisition cost when compared to surimi. Sensory results confirmed the acceptance of consumers regarding fishburgers made of Tilapia minced meat and surimi, minced meat fishburger presenting better acceptance and potential for consumption.

\section{ACKNOWLEDGMENTS}

This study received financial support from the Conselho Nacional de Desenvolvimento Científico e Tecnológico of Brazil (CNPq) and Universidade Federal Fluminense (UFF).

\section{REFERENCES}

ASSOCIATION of Official Analytical Chemists. Official methods of analysis. 16th ed. Arlington: AOAC, 1995. 2v.

BRASIL. Ministério da Agricultura. Secretaria Nacional de Defesa Agropecuária. Laboratório Nacional de Referência Animal (LANARA). Métodos analíticos oficiais para controle de produtos de origem animal e seus ingredientes: Métodos Físico Químicos. Brasilia: MAPA, 1981. 123p. 
BRASIL. Ministério da Agricultura e do Abastecimento. Instrução Normativa n.20 de 31 de julho de 2000. Regulamentos técnicos de identidade e qualidade de almôndega, fiambre, hambúrguer, kibe, presunto cozido e de presunto. Diário Oficial da União, 2000. Seção 1, p.7.

BRASIL. Ministério da Saúde. ANVISA. Resolução número 12, de 02 de janeiro de 2001. Aprova o Regulamento Técnico sobre os Padrões Microbiológicos para Alimentos. Diário Oficial da República Federativa do Brasil, Brasilia, DF, 2 janeiro 2001. Seção 1.

BRASIL. Ministério da Agricultura, Pecuária e Abastecimento. Instrução Normativa $\mathrm{n}^{\circ}$. 62, de 26 de agosto de 2003. Oficializa os Métodos Analíticos Oficiais para Análises Microbiológicas para Controle de Produtos de Origem Animal e Água. Diário Oficial da República Federativa do Brasil, Brasilia, DF, 19 setembro 2003. Seção 1. p.14.

BRASIL. Instituto Brasileiro do Meio Ambiente e dos Recursos Naturais Renováveis (IBAMA). Estatística da pesca 2007-Brasil: grandes regiões e unidades da federação. Brasilia: IBAMA, 2007. 151p.

COELHO, G.M.; WESCHENFELDER. A.V.; MEINERT, E.M. et al. Effects of starch properties on textural characteristics of fish burgers: sensory and instrumental approaches. Bol. Centro Pesq. Proc. Alim., v.25, p.37-50, 2007.

CHEN, H.H.; HUANG, C.Y. Rheological properties of HPMC enhanced surimi analyzed by small- and large-strain tests II: Effect of water content and ingredients. Food Hydrocoll., v.22, p.313-322, 2008.

COUSIN, M.A.; JAY, J.M.; VASAVADA, P.C. Psychotropic Microorganisms. In. DOWES, F.P; ITO, K. Compendium of methods for the microbiological examination of food. 4nd ed. Washington: American Public Health Association (APHA), 2001. Cap. 13, p.159-166.

FRANCO, R.M.; MANTILLA, S.P.S. Escherichia coli em cortes de carne bovina (acém): avaliação de metodologia e sensibilidade de antimicrobianos aos sorovares predominantes. In: SEMINÁRIO DE INICIAÇÃO CIENTÍFICA E PREMIO UFF VASCONCELOS TORRES DE CIÊNCIA E TECNOLOGIA, 14., 2004, Rio de Janeiro. Anais... Rio de Janeiro: UFF, 2004. CD.
KIRSCHINIK, P.G.; MACEDO-VIEGAS, E.M. Efeito da lavagem e da adição de aditivos sobre a estabilidade de carne mecanicamente separada de Tilápia do Nilo (Oreochromis niloticus) durante estocagem a $-18^{\circ} \mathrm{C}$. Cienc. Tecnol. Alim., v.29, p.1-7, 2009.

KUHN, C.R.; PRENTICE-HERNÁNDEZ，C.; VENDRUSCOLO, J.L.; SOARES, J.D. Surimi of King Weakfish (Macrodon ancylodon) Wastes: Texture Gel Evaluation with Protease Inhibitors and Transglutaminase. Brazilian Arch. of Biol. Technol., v.47, p.895-901, 2004.

MANLEY, C.; MANKOO, A. Surimi seafood flavors. In: PARK, J.W. Surimi and surimi seafood. 2nd ed. Boca Raton: Taylor \& Francis Group, 2004. Cap. 14, p.709 -748.

MARCHI, J.F.; COELHO, D.T.; RODRIGUES, V.P.; GOMES, J.C. Desenvolvimento e Avaliação de Produtos à Base de Polpa e Surimi Produzidos a Partir de Tilápia Nilótica, Oreochromis niloticus. In: INTERNATIONAL SYMPOSIUM ON TILAPIA AQUACULTURE, 5., 2000, Rio de Janeiro. Anais... Rio de Janeiro: Revista Panorama da Aquicultura, 2000. p.426434.

MARENGONI, N.G.; POZZA, M.S.S.; BRAGA, G.C. et al. Caracterização microbiológica, sensorial e centesimal de fishburgers de carne de tilápia mecanicamente separada. Rev. Bras. Saúde Prod. Anim., v.10, p.168-176, 2009.

MELLO, S.C.R.P.; FREITAS, M.Q.; SÃO CLEMENTE, S.C. et al. Caracterização química e bacteriológica de polpa e surimi obtidos do espinhaço residual da filetagem de tilápia. Rev. Cienc. Rural, v.40, p.648-653, 2010.

MERCK. Microbiology Manual. Berlin: MERCK, 2002. 407p.

MORTON, R.D. Aerobic plate corint. In. DOWES, F.P.; ITO, K. Compendium of methods for the microbiological examination of food. 4nd ed. Washington: American Public Health Association (APHA), 2001. Cap.7, p.63-67.

REGENSTEIN, J.M. The potencial for minced fish. Food Technol., v.3, p.101-106, 1986.

SIMÕES, M.R.; RIBEIRO, C.F.A.; RIBEIRO, S.C.A. et al. Composição físico-química, microbiológica e rendimento do filé de tilápia tailandesa (Oreochromis niloticus). Cienc. Tecnol. Alim., v.27, p.608-613, 2007. 
Development and bacteriological...

STATISTICAL analysis Sistem. SAS Institute. SAS User's guide., 6.04ed. Cary, NC, 1999. 956 $\mathrm{p}$.

STONE, H.; SIDEL, J.L. Sensory evaluation practice. 2nd ed. San Diego: Academic, 1992. $338 \mathrm{p}$.

TOKUR, B.; POLAT, A.; BEKLEVIK, G.; ÖZKÜTÜK, S. Changes in the quality of fishburger produced from tilapia (Oreochromis niloticus $)$ during frozen storage $\left(-18^{\circ} \mathrm{C}\right)$. Eur. Food Res. Technol., v.218, p.420 - 423, 2004.
VIEIRA, R.H.S.F. Normas e padrões microbiológicos para o pescado. In. VIEIRA, R.H.S.F. Microbiologia, higiene e qualidade do pescado. São Paulo: Varela, 2004. Cap. 16, p.203- 210 .

WEICHERT, M.A.; MELLO, S.C.R.P.; ESPÍNDOLA, L.M. O consumo de tilápias e rãs nas cidades do Rio de Janeiro e Niterói. Rev. Panor. Aquicult., v.17, p.37-41, 2007. 